\title{
Hormonal Changes in Puberty I. Correlation of Serum Luteinizing Hormone and Follicle Stimulating Hormone with Stages of Puberty, Testicular Size, and Bone Age in Normal Boys
}

\author{
Ian M.Burr, Pierre G. Sizonenko, Selna L. Kaplan and Melvin M. Grumbach ${ }^{[63]}$ \\ Department of Pediatrics, University of California San Francisco Medical Center, \\ and Pediatric Multiphasic Screening Program, Kaiser-Permanente Foundation, San Francisco, California, USA
}

\section{Extract}

The concentration of luteinizing hormone (LH) and follicle stimulating hormone (FSH) in serum was determined using a double antibody radioimmunoassay method in each of 106 normal boys aged 5-16 years. The boys were grouped according to the stage of puberty $\left(\mathrm{P}_{\mathbf{1}}-\mathrm{P}_{5}\right)$ using the classification of TANNER.

The serum LH and FSH, LH/FSH ratio, and testicular volume index (TVI) for boys prepuberty $\left(\mathrm{P}_{1}\right)$ and at different stages of puberty $\left(\mathrm{P}_{2}-\mathrm{P}_{5}\right)$ are shown in figure 1 and table $\mathrm{I}$. The mean value of $\mathrm{LH}$ in prepubertal boys was $4.2 \mathrm{ng} / \mathrm{ml}$, which steadily rose to a concentration of $5.3 \mathrm{ng} / \mathrm{ml}$ at $\mathrm{P}_{4-5}$. The differences between the values for $\mathrm{LH}$ in early puberty $\left(\mathrm{P}_{2}\right)$ and at a more advanced stage of puberty $\left(\mathrm{P}_{4-5}\right)$ were statistically significant. The mean value for serum FSH in the prepubertal boy was $1.4 \mathrm{ng} / \mathrm{ml}$. Serum FSH rose steadily through the early stages of puberty $\left(\mathrm{P}_{1}-\mathrm{P}_{3}\right)$ with no further rise from $P_{3}$ to $P_{4-5}$. These changes were reflected in the LH/FSH ratio which fell between $\mathrm{P}_{1}$ and $\mathrm{P}_{2}$, but increased between $\mathrm{P}_{2}$ and $\mathrm{P}_{4}$. Testicular size (TVI) showed a gradual increase from $\mathrm{P}_{1}$ through $\mathrm{P}_{4-5}$.

A comparison of serum LH and FSH, LH/FSH ratio, and TVI with chronological age is indicated in table II. A slight increase in the mean levels of serum LH and FSH was observed from age 9 to age 12 with a continued rise to 15 years and older. Serum LH seemed to rise at an earlier age than serum FSH. The TVI showed a definite increase from chronologic age 8 through 11 . A pronounced change in testicular size from age 11 through 15 was observed during the period of sharp rise in serum FSH.

The correlation of bone age with concentrations of LH and FSH in serum, LH/FSH ratio, and TVI is shown in table III. A significant rise in LH was seen in boys with a bone age of 9-10 years, with a further increase at a bone age of 13-15 years and older. Serum FSH showed a steady increment from a bone age of 11 to 14 years. The most pronounced increase in TVI was seen at a bone age of 11 through 15 years.

The relation of concentrations of LH and FSH in serum and LH/FSH ratio to the TVI is presented in table IV. Mean LH and FSH showed a gradual rise from a TVI of $<2$ to 10.1-12. Serum LH rose and serum FSH fell, however, with the increase in TVI from 10.1-12 to 12.1-16.

In four patients with chromatin-positive seminiferous tubular dysgenesis (Klinefelter's syndrome), the mean serum $\mathrm{LH}$ concentration was $11.3 \mathrm{ng} / \mathrm{ml}$ and the mean serum FSH concentration was $21.6 \mathrm{ng} / \mathrm{ml}$. 
The mean serum LH in 14 patients with multiple pituitary hormone deficiencies was $2.1 \mathrm{ng} / \mathrm{ml}$ and the mean serum FSH was $1.5 \mathrm{ng} / \mathrm{ml}$. The small differences in the concentration of LH and FSH in prepubertal boys compared with that observed in children with hypopituitarism stress the need for further definition of the sensitivity of the assay for serum samples. The serum values reported are of relative not absolute significance.

\section{Speculation}

The detection of serum FSH and LH prior to puberty, and the increase in serum FSH and LH coincident with advancing puberty suggests 1) that the hypothalamic-pituitary-testicular axis is functional before puberty, and 2) that the onset of puberty may be associated with a change in sensitivity of the hypothalamus to feedback by testicular steroids.

\section{Introduction}

Until recently, determination of gonadotropins in human biological fluids was limited to the use of bioassay procedures of variable specificity, precision, and sensitivity. Even with improvements in methodology $[1,10,34]$, few estimates of plasma gonadotropins by bioassay are available, and only in subjects with high plasma concentrations or utilizing large plasma pools $[2,23,28]$. The development of methods for isolation and purification of human pituitary luteinizing hormone (LH) and follicle stimulating hormone (FSH) $[36,37,41,43]$ and the discovery of highly sensitive radioimmunoassay methods for quantifying polypeptide hormones [6] has led to the adaptation of radioimmunoassay techniques for the determination of $\mathrm{LH}$ and $F S H$ in serum and urine $[4,12,13,24,29,30,33,42$, $44,50]$. Only fragmentary data, however, are available on the values for serum gonadotropins in prepubertal and pubertal children $[12,20,33,35,39,42,44]$.

In this report, serum FSH and LH were measured by radioimmunoassay in 106 normal boys, aged 5-16 years, in an attempt to define the changes in gonadotropin secretion that occur with sexual maturation. The values for serum FSH and LH were correlated with chronologic and bone age, testicular size, and with clinical assessment of sexual maturation. For purposes of comparison with the values obtained in normal subjects, sera from 14 hypopituitary patients and 4 patients with chromatin-positive seminiferous tubular dysgenesis syndrome were assayed for both LH and FSH.

Materials and Methods
Subjects
One-hundred and six normal boys, aged 5-16 years,
who attended the Kaiser Foundation OutpatientClinic
for a routine annual multiphasic screening examina-
tion were the subjects of this study; they were examined
for signs of pubertal development. This was assessed
by skin texture, presence of acne, body odor, the amount, texture, and distribution of facial, axillary, and pubic hair, voice change, and penile and testicular size.

Testicular size was determined on all but one patient by measuring the length and width of each testis. An assessment of testicular volume was made by multiplying the testicular length (centimeter) by breadth, adding the products from each side and dividing by two; this value was termed the 'testicular volume index' (TVI). The boys were assigned to one of five grades of sexual development, based on a modification of the criteria of TANNER [48]: $P_{1}$, prepubertal, infantile in development; $P_{2}$, pubertal, with evidence of slightly increased testicular size and minimal scrotal or pubic hair; $\mathrm{P}_{3}$, pubertal, with further increase in testicular and phallic size, more pubic and some axillary or facial hair, or both; $\mathrm{P}_{4}$, pubertal, with moderate pubic, axillary, and facial hair, voice change, acne, or adult body odor, or both; and $\mathrm{P}_{5}$, adult body habitus, hair distribution, and genitalia.

Bone age was determined on all but three patients from radiographs of the wrist, using the standards of Greulich and Pyle [17].

Blood was drawn from all patients for the measurement of serum LH and FSH. In addition, sera from 14 children, from 5 to 21 years, all with proven multiple pituitary hormone deficiencies [15], and 4 patients, aged 15-20 years, with chromatin-positiveseminiferous tubular dysgenesis syndrome (confirmed by karyotype analysis) were assayed for gonadotropin levels. These procedures were a routine part of the multiphasic screening evaluation. Informed consent was obtained from all subjects in this study.

\section{Radioimmunoassay of $\mathrm{LH}$}

Luteinizing hormone was assayed by a double antibody [32] radioimmunoassay technique. Antisera to human chorionic gonadotropin (HCG), 10,000 IU/ vial [52], were raised in white New Zealand rabbits by subcutaneous injection of 1,000 IU emulsified with complete Freund's adjuvant every 10-14 days. When a suitable titer of anti-HCG was obtained booster 
injections, also of 1,000 IU, were given at 2- to 4-week intervals. Antisera that bound approximately $40 \%$ of labeled tracer $\mathrm{LH}$, while allowing displacement of tracer by small quantities of unlabeled $\mathrm{LH}$, were selected for use in the assay. Antisera were absorbed with a kaolin extract of urine from a hypopituitary infant and with human FSH, $100 \mathrm{ng} / \mathrm{ml}$ of $1: 100$ antisera [53]. This concentration of FSH did not displace labeled LH from the absorbed anti-HCG when added to the assay system. Human thyroid stimulating hormone (TSH), however, displaced labeled LH from the anti-HCG in the assay system. This displacement could be accounted for by a small contamination of the TSH by LH, and minor cross-reaction [8]. The binding characteristics of the antiserum to HCG were similar to those of an antiserum to HCG distributed by the National Pituitary Agency [54].

A purified preparation of human LH, LER-960 [55], was used as a standard and for iodination. This preparation had a potency by bioassay of $923 \mathrm{IU} / \mathrm{mg} 2 \mathrm{nd}$ IRP [56], $1 \mathrm{ng}$ of which by immunoassay was the equivalent of 2.2-2.4 mIU 2nd IRP.

Luteinizing hormone was iodinated by a modification [21] of the method of HUNTER and GREenwOOD [19]. Five micrograms of $\mathrm{LH}$ were added to $0.025 \mathrm{ml}$ of $0.5 \mathrm{~m}$ phosphate buffer, $\mathrm{pH} 7.5$, followed by $2 \mathrm{mCi}$ of 'carrier-free' ${ }^{131} \mathrm{I}-\mathrm{Na}$ [57] of high specific activity $(300 \mathrm{mCi} / \mathrm{ml})$; then, in rapid order, $0.02 \mathrm{ml}$ of chloramine $\mathrm{T}(24 \mathrm{mg} / 10 \mathrm{ml}), 0.08 \mathrm{ml}$ of sodium metabisulfite $(35.2 \mathrm{mg} / 10 \mathrm{ml})$, and $0.05 \mathrm{ml}$ of human serum were added. The efficiency of the iodination procedure was monitored by chromatoelectrophoresis of an aliquot of the iodination mixture on Whatman no. $3 \mathrm{MC}$ in phosphate buffer, pH 7.8 at $4^{\circ}$ (the labeled protein remains at the origin and the free ${ }^{131} I$ moves toward the anode). The mean efficiency for 12 iodinations was $70 \% \pm 5(\mathrm{sD})$. Labeled hormone was separated from free iodide by passing the iodination mixture through a 10-cm by 1-cm G-75 Sephadex column equilibrated with $0.01 \mathrm{~m}$ phosphate buffer, $\mathrm{pH} 7.8$, and bovine serum albumin. Aliquots of $0.5 \mathrm{ml}$ were collected and peak counts were obtained between the 6 th and 8 th tubes (protein peak) and 13th and 14th tubes (iodide peak). Aliquots of the protein peak were checked for 'damage' by paper chromatoelectrophoresis on Whatman no. $3 \mathrm{MC}$ in $0.01 \mathrm{M}$ phosphate buffer, $\mathrm{pH} 7.8$ at $4^{\circ}$. 'Damage' estimated by this procedure was consistently less than $10 \%$. The aliquot containing the least damaged ${ }^{131}$ I-LH was used in the assay procedure. The specific activity of the ${ }^{131} \mathrm{I}-\mathrm{LH}$ varied from 200 to $300 \mu \mathrm{Ci} / \mu \mathrm{g}$. When ${ }^{131} \mathrm{I}-\mathrm{LH}$ from the first Sephadex peak was passed through a $10-\mathrm{cm}$ by $1-\mathrm{cm}$ G-75 column and a $30-\mathrm{cm}$ by $1-\mathrm{cm}$ G-200 column immediately after iodination, and again after 5 and 10 days storage at $-20^{\circ}$, single peaks of radioactivity were ob- tained (suggesting that significant deiodination or polymerization had not occurred).

Each assay was performed within 2 days of iodination. Assays were run in two stages: 1) ${ }^{131} \mathrm{I}-\mathrm{LH}(10,000$ counts equivalent to $0.0125-0.025 \mathrm{ng} \mathrm{LH}$ ) was incubated with unlabeled LH, 0.05-5.0 ng (standards) or $0.1 \mathrm{ml}$ of serum and $0.1 \mathrm{ml}$ of $1: 20,000$ rabbit antiHCG. The diluent, $0.01 \mathrm{~m}$ phosphate $-0.15 \mathrm{M}$ saline buffer, containing $0.01 \mathrm{~m}$ EDTA and $1 \% \mathrm{BSA}$, corrected to $\mathrm{pH} 7.8$, was added to make a total volume of $1 \mathrm{ml}$. Control tubes were set up with each assay, with omission of unlabeled hormone in one set and antiHCG serum and unlabeled hormone in another. No nonspecific binding of labeled hormone was observed in any assay. Control tubes were also set up for each serum sample omitting the first antibody; 2) After an incubation period of 5 days, sheep anti-rabbit gamma globulin, $0.05 \mathrm{ml}$, and 1:50 normal rabbit serum (NRS), $0.05 \mathrm{ml}$, were added to all tubes, including controls and standards. Normal human serum (NHS), $0.1 \mathrm{ml}$, was added to the standards and to standard control tubes and $0.1 \mathrm{ml}$ buffer to the remainder. The final volume in all tubes was $1.2 \mathrm{ml}$.

Normal human serum was added to standards to produce identical binding conditions in standards and samples. Previously reported data [7] from this laboratory indicated that NHS augmented the degree of precipitation in some sheep anti-rabbit gamma globulin systems, an effect independent of the presence of EDTA, heparin, NRS, or of the buffer used. The LH present in the NHS, added to the precipitating (second) antibody, did not produce displacement of the tracer from the first antibody.

Under the above assay conditions, the binding of ${ }^{131} \mathrm{I}-\mathrm{LH}$ in the absence of unlabeled hormone ranged from $35-45 \%$ with significant displacement of ${ }^{131}$ I-LH by $0.1 \mathrm{ng}$ of unlabeled hormone. Difference between duplicates over the range of $20-45 \%$ binding was $2 \%$; the mean value for six assays of a postmenopausal serum was $20 \mathrm{ng} / \mathrm{ml} \pm 1.5$ (SD) (LER-960). The mean recovery of unlabeled hormone added to the assay system in the presence of serum was $104 \% \pm 9$ (sD).

\section{Radioimmunoassay of FSH}

The FSH assay was conducted in a similar manner and full details are given in the accompanying paper [46]. Human FSH, LER-869-2 [55] (1 ng, was equivalent to $1.79 \mathrm{mIU}, 2$ 2nd IRP by immunoassay; 2,782 IU/mg 2nd IRP by bioassay) was used for iodination and standards. Rabbit antiserum to human FSH [58] (Midgley D33-7) and sheep anti-rabbit gamma globulin were utilized. The sensitivity of this assay allowed estimation of $0.2 \mathrm{ng}$ of FSH; 0.2-ml aliquots of serum were assayed when maximum sensitivity was required. Mean difference between duplicates was $2 \%$, and the 
mean value of postmenopausal serum pool was 27.4 $\mathrm{ng} / \mathrm{ml} \pm 2.4$ (SD) over six assays; mean recovery of unsabeled FSH when added to systems containing human lerum was $97 \%$ (range: 90-112).

Standards and antisera for both assays were stored in small aliquots at $-20^{\circ}$. There was no deterioration of standards over a 6 -month period under these conditions or any alteration in the binding characteristics of the antisera [7].

Statistical analyses of the data were made by the Wilcoxon rank test and confirmed by Student's $t$ test when applicable.

\section{Results}

The number of boys in each stage of puberty and the values obtained for concentrations of LH and FSH in serum, the LH/FSH ratio, and testicular volume index (TVI) in each stage of pubertal development are shown in table I and figure 1 . The mean chronological age and mean bone age for boys in stage $P_{2}$ was $11^{6} / 12$ years (range: 9-143/12 chronological age; $85 / 12^{-13}$ years bone age). The LH levels rose steadily through the three stages of puberty from a prepubertal mean value of $4.2 \mathrm{ng} / \mathrm{ml}$. The differences between values for
$P_{1}$ and $P_{3}$, and $P_{2}$ and $P_{4-5}$ were statistically significant. The mean prepubertal serum FSH concentration of $1.4 \mathrm{ng} / \mathrm{ml}$ rose steadily through the first two stages of puberty. Increases from $P_{1}$ to $P_{2}$, and $P_{2}$ to $P_{3}$ were statistically significant. Unlike the LH levels, FSH levels did not continue to rise from $\mathrm{P}_{3}$ to $\mathrm{P}_{4-5}$. The $\mathrm{LH} / \mathrm{FSH}$ ratio fell from a prepubertal mean of 3.3 to a mean of 1.9 in $\mathrm{P}_{3}$, corresponding to the rise in $\mathrm{FSH}$ levels. From $\mathrm{P}_{3}$ to $\mathrm{P}_{4^{-5}}$ the ratio tended to rise, reflecting a continued increase in serum LH concentration without a corresponding increase in FSH concentration. Testicular size increased steadily from $\mathrm{P}_{1}$ to $\mathrm{P}_{4-5}$.

The serum LH and FSH concentrations, LH/FSH ratio, and TVI are shown in relation to chronological age in table II. There was some fluctuation in the mean levels of $\mathrm{LH}$ and $\mathrm{FSH}$ from age 5 to 9, and a slight but statistically significant increase from age 9 to 12 , with a continuing rise to 15 years and older. Mean serum FSH concentrations rose from 9 to 11 years. There was a demonstrable rise in both $\mathrm{LH}$ and FSH serum concentrations prior to the mean age at which the earliest clinical signs of puberty could be recognized. There was suggestive evidence of an increase in the concentration of serum LH prior to that of serum FSH.

Table I. Mean concentrations of $\mathrm{LH}$ and FSH in serum, LH/FSH ratio, and testicular volume index at different stages of puberty in 106 boys

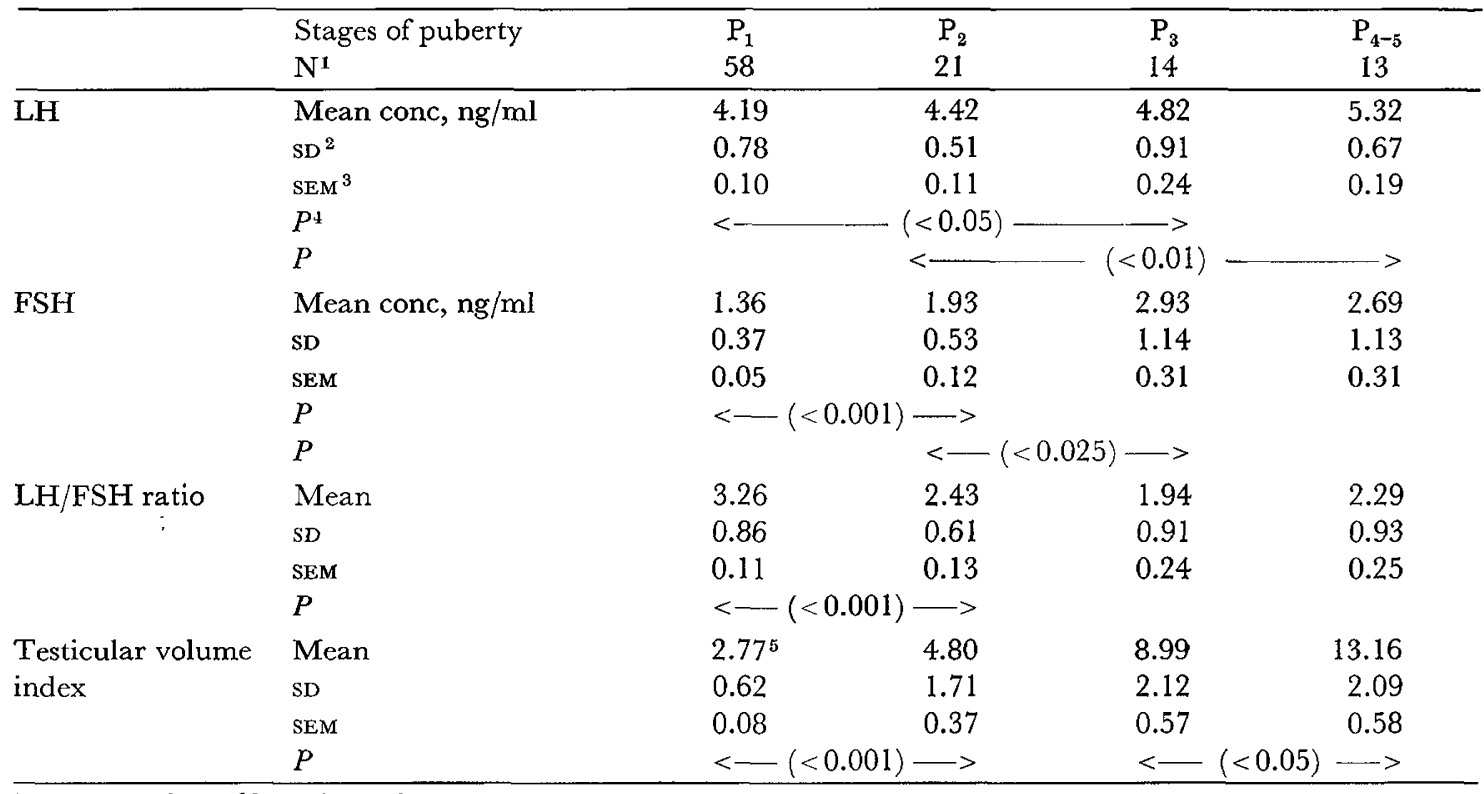

$\mathrm{N}=$ number of boys in each group.

${ }^{2} \mathrm{SD}=$ standard deviation.

${ }^{3}$ SEM $=$ standard error of the mean.

${ }^{4} P=$ probability estimation; the arrows delineate the groups compared.

${ }_{5}^{5}$ Testes were not measured in one boy. 
The mean LH/FSH ratio decreased between 8 and 13 years of age, followed by a rise over the next 2-3 years, which is attributable to a proportionately greater increase in the $\mathrm{LH}$ values. The TVI increased from age 8 through 11 with a sharp increase in size from chronological age 11 through age 15 , coinciding with the major rise in serum FSH.

The serum LH and FSH concentrations, LH/FSH ratio, and TVI are compared with bone age in table III. The mean serum LH concentration for boys with bone age of 9 years $\left(8^{7} /{ }_{12}-9^{6} / 12\right)$ was less than that for the groups with bone ages of 8 or of 10 years. There

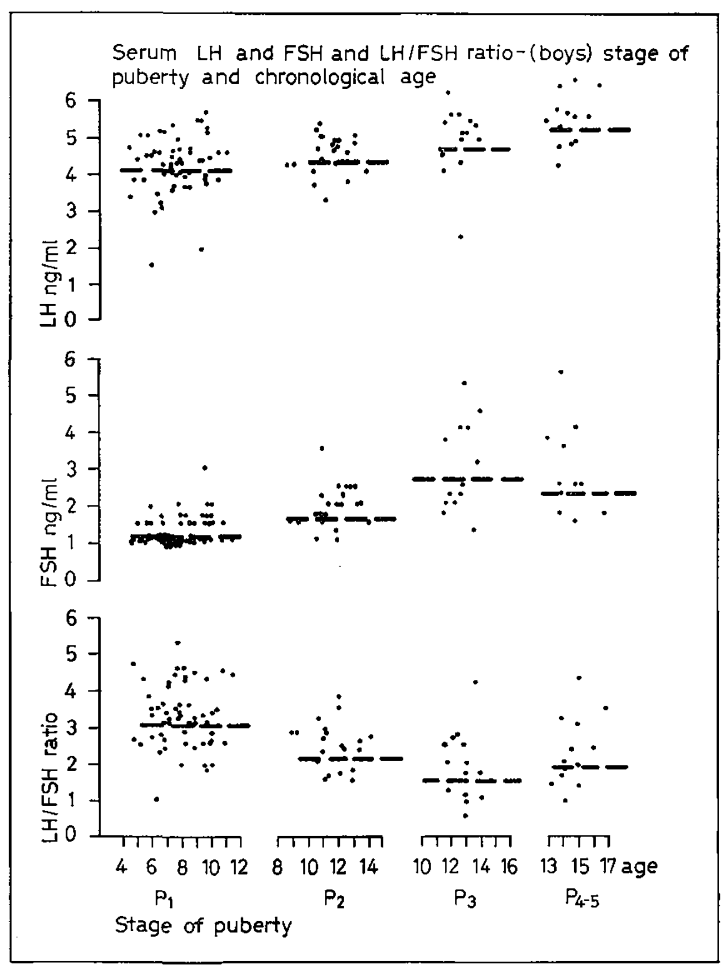

Fig. 1. Comparison of LH $(\mathrm{ng} / \mathrm{ml})$, FSH $(\mathrm{ng} / \mathrm{ml})$, and LH/FSH ratio in 106 normal boys prepuberty $\left(\mathrm{P}_{1}\right)$ and at different stages of puberty $\left(\mathrm{P}_{2}-\mathrm{P}_{5}\right)$. The mean for each group is indicated by the dashed lines.

1 The ages of patients in each age group range from 5 months less to 6 months greater than the indicated age.

${ }^{2} \mathrm{~N}=$ number of boys.

${ }^{3} \mathrm{SD}=$ standard deviation.

${ }^{4} \mathrm{SEM}=$ standard error of the mean.

${ }^{5} P=$ probability estimation; the arrows delineate the groups compared.

${ }^{6}$ Significant fall in values.

7 Testes were not measured in one boy.

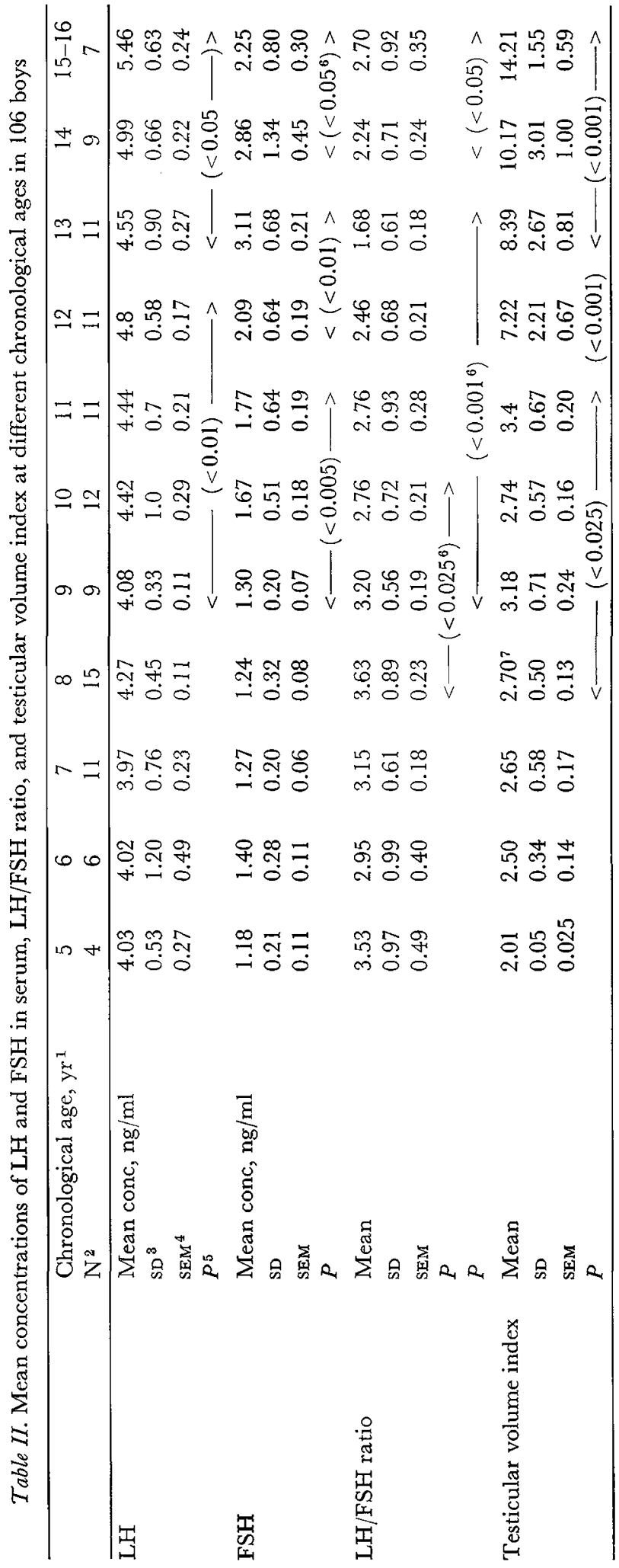


Table III. Mean concentrations of LH and FSH in serum, LH/FSH ratio, and testicular volume index at different bone ages in 103 boys

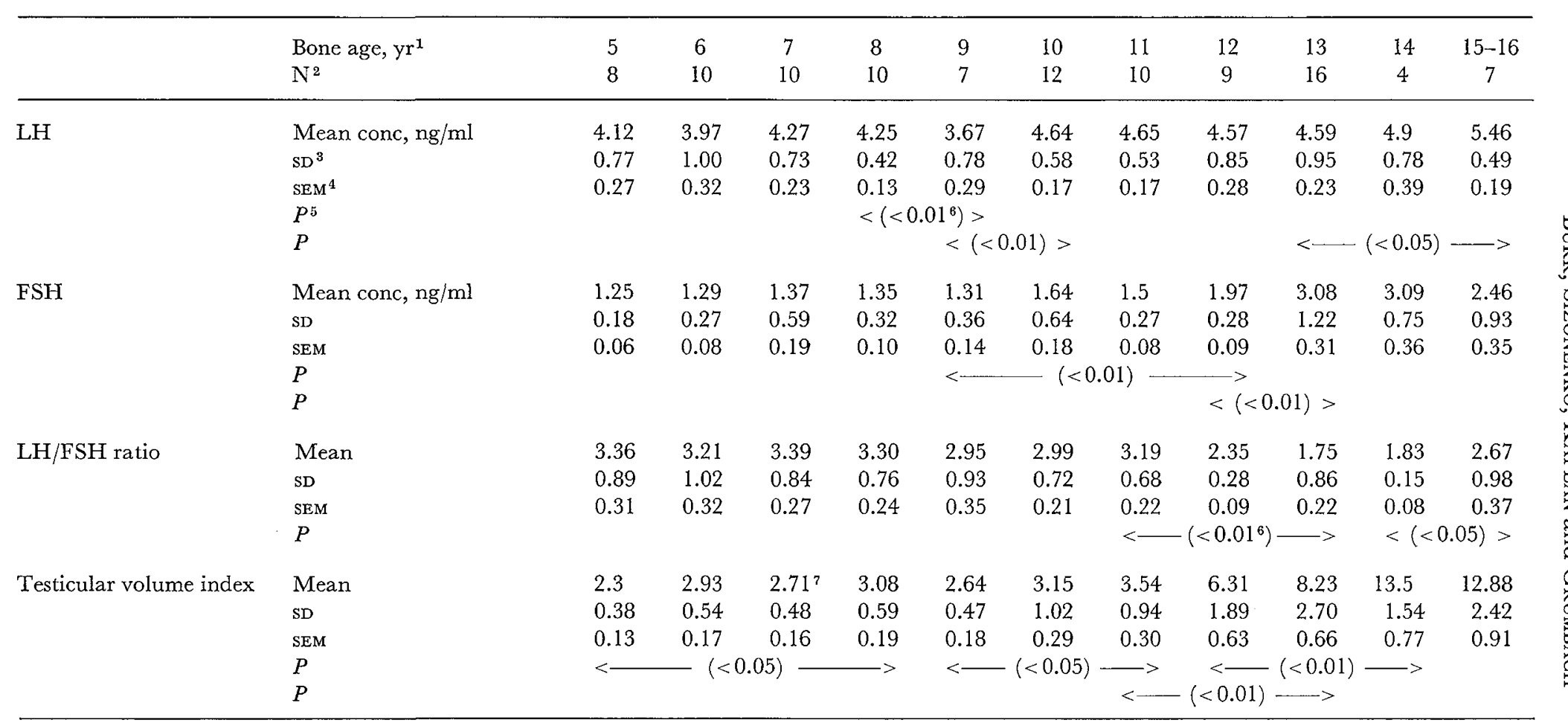

1 The ages of patients in each age group range from 5 months less to 6 months greater than the indicated age.

${ }^{2} \mathrm{~N}=$ number of boys.

${ }^{3} \mathrm{SD}=$ standard deviation.

${ }^{4} \mathrm{SEM}=$ standard error of the mean.

${ }^{5} P=$ probability estimation; the arrows delineate the groups compared.

${ }^{6}$ Significant fall in values.

7 Testes were not measured in one boy. 
was a significant rise in $\mathrm{LH}$ in boys with a bone age of 9-10 years, with a plateau to bone age 13, and a further rise from bone age 13 to 15 years and older. The mean serum FSH concentration rose gradually from a bone age of 11 to 14 years. Both $\mathrm{LH}$ and FSH concentrations in serum rose at a lower bone age than the mean bone age of the boys who exhibited early signs of puberty $\left(\mathrm{P}_{2}\right)$ on examination.

The LH/FSH ratio fell from bone age 11 to 13 years, then rose between 14 and 15 years of age. The TVI rose slightly from bone age 9 through 11 , with a major increase from 11 through 15 years.

Serum $\mathrm{LH}$ and FSH concentrations and the $\mathrm{LH}$ / FSH ratios are tabulated in relation to the TVI in table IV. Mean LH values increased gradually from a TVI $<2$ to 12.1-16. Values for FSH also increased gradually with changing TVI; however, unlike LH they fell as the TVI increased from $10.1-12$ to $12.1-16$. The LH/FSH ratio fell from a TVI of $<2$ to $10.1-12$, then rose at the last stage from 10.1-12.0 to 12.1-16.

Values in Hypopituitarism and in Primary Gonadal Failure

The mean serum LH concentration in 22 determinations in the 14 patients with multiple pituitary hormone deficiencies was $2.1 \mathrm{ng} / \mathrm{ml}$ (sD 1.11; SEM 0.24), and the mean serum FSH concentration was 1.53 $\mathrm{ng} / \mathrm{ml}$ (sD 0.66; sEM 0.14). The difference in LH values for the hypopituitary patients and the normal prepubertal boys $\left(P_{1}\right)$ was of borderline statistical signifi- cance $(P<0.05)$. There were no detectable differences in FSH values between these two groups. The mean serum LH concentration in the four patients with chromatin-positive seminiferous tubular dysgenesis (Klinefelter's syndrome) was $11.25 \mathrm{ng} / \mathrm{ml}$ (sD 2.89; SEM 1.44) and the mean serum FSH concentration was $21.6 \mathrm{ng} / \mathrm{ml}$ (SD 4.35 ; SEM 2.2).

\section{Discussion}

The serum values reported are of relative and not absolute significance; unresolved problems in the assay of serum FSH and LH impose limitations on the interpretation of data. Such factors as the purity and stability of the pituitary FSH and LH standard, possible differences in the immunochemical reactivity of serum and pituitary gonadotropins, the variance for low serum values, the 'floor' of the assay for samples of serum, the effects of different serum LH/FSH ratios, and the specificity of currently available anti-human FSH and LH sera have not been completely evaluated. These constraints are of special importance in interpreting the significance of prepubertal serum gonadotropin values. Further, the design of this study is crosssectional.

Some of the factors affecting the double antibody radioimmunoassay technique for the assay of serum LH and FSH have been reported previously and the

Table IV. Mean concentrations of $\mathrm{LH}$ and FSH in serum and LH/FSH ratio at different stages of testicular development in 105 boys

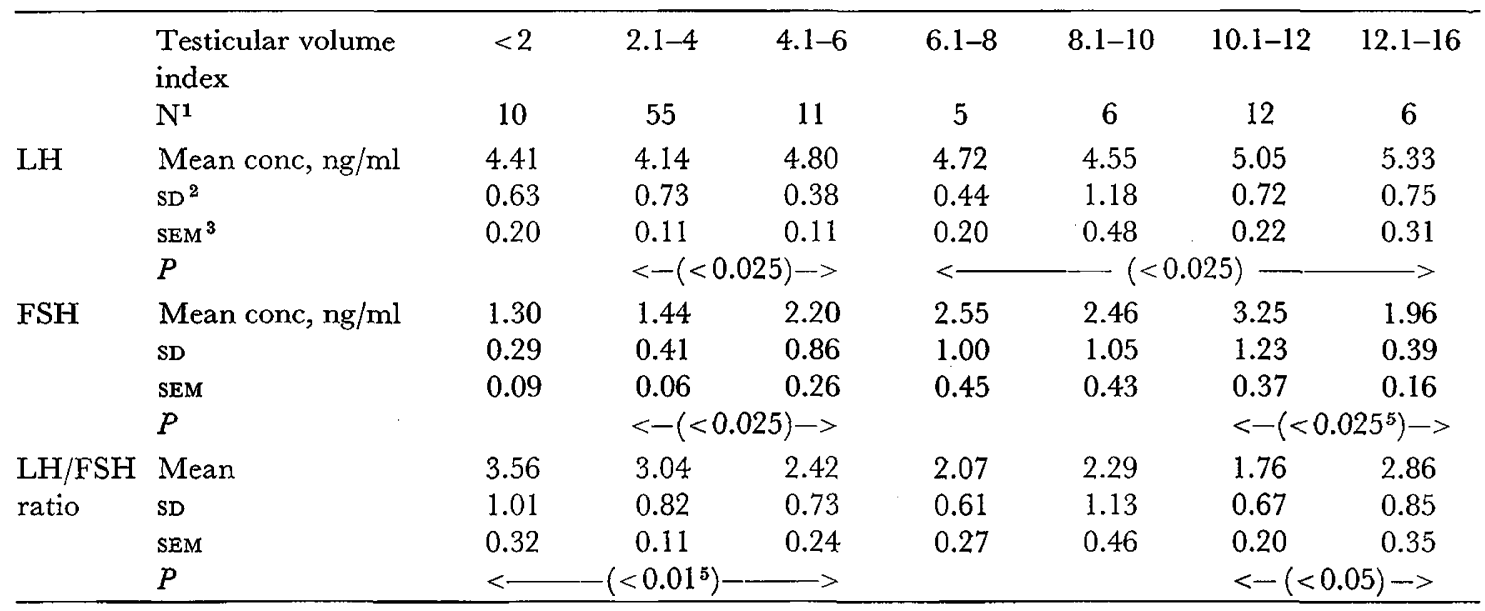

${ }^{1} \mathrm{~N}=$ number of boys.

${ }^{2} \mathrm{SD}=$ standard deviation.

${ }^{3}$ SEM $=$ standard error of the mean.

${ }^{4} P=$ probability estimation; the arrows delineate the groups compared.

${ }^{5}$ Significant fall in values. 
importance of correcting for the enhancement of precipitation due to human serum has been stressed [7]. No cross-reaction occurred between LH and FSH in either assay system. Though it has been demonstrated previously that antisera to HCG bind labeled TSH, the degree of cross-reaction is insufficient to interfere with the assay of LH in normal human serum [8].

In these systems, $0.1 \mathrm{ng}$ of purified $\mathrm{LH}$ or $0.2 \mathrm{ng}$ of FSH in buffer can be measured; however, the sensitivity of the radioimmunoassay systems for the measurement of serum LH and FSH may be different. This problem, of special importance in the precise quantification of low serum values, requires further study. The lack of differences in serum FSH concentrations between hypopituitary dwarfs and prepubertal boys, and the relatively small but significant differences in the concentrations of serum LH, further stress the need for defining the sensitivity of the assay for serum samples.

The standard LH preparation used in these studies had the immunologic equivalent of 2.2-2.4 mIU 2nd IRP for $1 \mathrm{ng}$ of LER-960. The levels reported are similar to those described in prepubertal children by ODELl et al. [33], SAXENA et al. [42], and Root et al. [39] though higher than those obtained by JoHANson et al. [20] and Schalch et al. [44]. The values of FSH reported here for prepubertal boys (1.4 $\mathrm{ng}$ of LER869-2 is equivalent to $2.5 \mathrm{mIU}$ 2nd IRP-HMG) are slightly lower than those reported by SAXENA et al. [42] and Rartr et al. [35], but similar to those of Schalch et al. [44] and FAIMAN and RYAN [12]. In the present study, a significant rise has been documented in the concentration of both serum LH and FSH from prepuberty through the first stages of puberty, the increase in serum FSH correlating closely with the marked increase in testicular size observed during this period.

The change in gonadotropin concentration with increase in chronological and bone age is of particular interest. In general, there was good correlation between the changes associated with increase in bone age and with chronological age. It has been suggested $[11,48]$ that bone age is more physiologically significant and, therefore, the better correlate. When evaluating changes in serum gonadotropin concentration with bone age, it was observed that LH levels began to rise by 10 years then plateaued until age 13 (table III). These changes were associated with an initial slight increase in testicular growth. They preceded the first significant rise in FSH levels, which occurred at 12 years and were associated with a rapid increase in testicular size. The physiologic significance of the observed drop in $\mathrm{LH}$ concentration at the bone age of 9 is questionable since a similar change was not detected at a comparable chronological age.
There was a general tendency for serum LH and FSH levels to increase with bone and chronological age- - from the age of 10 to 11 years for $\mathrm{LH}$ and 12 years for FSH. The age at which an increase in the concentration of serum $\mathrm{LH}$ was observed was slightly earlier than the mean age $\left(11^{6} /{ }_{12}\right.$ years $)$ of the group considered to be in the first stage of puberty. The increase observed in serum LH and FSH levels with maturation are in accord with those reported for human $[5,40,51]$ and animal $[18,25,45]$ pituitary gonadotropin content, and for excretion in human urine determined by bioassays [38]. The magnitude of the change in urinary $\mathrm{LH}$ before and after the onset of puberty, however, was considerably greater in the study of RIFKIND et al. [38] than for the serum values in the present study.

The progressive increase in testicular size from a chronological and bone age of 11 years was comparable to the values reported previously $[11,49]$. The initial increase in testicular size correlates with the initial increase in serum LH and FSH values (table IV). The secondary and more marked increase in testicular size noted from chronological age 12 years $\left(11^{7} / 12^{-12} / 12\right)$ onward correlates well with the greatest interval increase in FSH concentration. This, together with previous findings that an appreciable increase in mitosis in the seminiferous tubules occurs at about 11 years of age [47] and that FSH stimulates seminiferous tubule development [14] and testicular size $[14,16]$, suggests that the increase in FSH accompanies the phase of rapid testicular growth. The observed increase in $\mathrm{LH}$ concentration at this stage may facilitate the action of FSH in producing an increase in testicular size, particularly in view of the enhanced effect of FSH on testicular size in the presence of $\mathrm{LH}$ under experimental conditions [27]. This slight increase in LH levels from bone age 9 to 10 years may also stimulate an initial [3,9] small rise in testosterone secretion.

The greater rise in $\mathrm{LH}$ concentration from bone age of 13 to 15 years and older, with a continued rapid increase in both testicular size and FSH concentration, corresponds temporally with the major increase in 17-ketosteroid [11] and testosterone excretion [3, 9]. A similar pattern of growth of the ventral prostate has been observed in immature rats [22].

During the late phase of rapid testicular development, levels of $\mathrm{LH}$ continue to rise while levels of FSH fall, suggesting that maintenance of testicular size and function requires less FSH than the maturation process. Further, the enhanced $\mathrm{LH}$ and testosterone levels at this time contribute to the continued development of spermatogenesis, the initiation of which may require a greater increase in the secretion of FSH [26].

The wide range in $\mathrm{LH}$ and $\mathrm{FSH}$ serum concentrations during all stages of puberty and through all chronological and bone ages suggests either marked 
individual variation in gonadotropin levels or, alternately, some fluctuation in gonadotropin release. Although the role of adrenal androgens in male puberty is not completely understood, the findings in the present study suggest that the first rise in serum LH coincides with a sharp increase in adrenal androgen secretion [11]. Whether LH has a significant indirect or direct effect on the alteration of adrenocortical function at puberty, however, remains to be determined [31].

The high gonadotropin levels in the patients with chromatin-positive seminiferous tubular dysgenesis syndrome were consistent with the serum LH and FSH concentrations in other studies [39, 42].

The present data provide information concerning the sequential events that take place at puberty in the male. Further interpretation of these findings are presented in the accompanying paper [46].

\section{Summary}

The concentrations of $\mathrm{LH}$ and FSH in serum were determined in each of 106 normal boys (5-16 years of age) using a double antibody radioimmunoassay method. The boys were grouped according to their stage of pubertal development $\left(P_{1}\right.$ through $\left.P_{5}\right)$, chronological and bone ages, and testicular size. The mean LH concentration in the prepubertal boys was $4.2 \mathrm{ng} / \mathrm{ml}$, rising steadily with maturation $\left(\mathrm{P}_{5}\right)$ to $5.3 \mathrm{ng} / \mathrm{ml}$; the corresponding FSH value in prepubertal boys was $1.4 \mathrm{ng} / \mathrm{ml}$ with a similar rise in early puberty to $2.9 \mathrm{ng} / \mathrm{ml}\left(\mathrm{P}_{3}\right)$, with a tendency to plateau prior to the attainment of complete maturation $\left(\mathrm{P}_{5}\right)$.

When the gonadotropin concentrations were plotted against chronological and bone age the mean LH concentration rose from $4.1 \mathrm{ng} / \mathrm{ml}$ at age 9 to a mean concentration of $5.5 \mathrm{ng} / \mathrm{ml}$ at $15-16$ years. Serum FSH levels rose steadily from age $9(1.3 \mathrm{ng} / \mathrm{ml})$ to the age of $13-14$ years $(3.1 \mathrm{ng} / \mathrm{ml})$ then appeared to decrease slightly.

The mean serum LH and FSH values in 14 hypopituitary children were 2.1 and $1.5 \mathrm{ng} / \mathrm{ml}$, respectively, and in 4 patients with chromatin-positive seminiferous tubule dysgenesis, 11.3 and $21.6 \mathrm{ng} / \mathrm{ml}$.

\section{References and Notes}

1. Albert, A.: Human urinary gonadotropin. Rec. Progr. Hormone Res. 12: 227 (1956).

2. Apostolakis, K.: Detection and estimation of pituitary gonadotropins in human plasma. J. clin. Endocrin. 19: 377 (1959).
3. August, G.P.; Tkachuk, M. and Grumbach, M.M.: Plasma testosterone-binding affinity and testosterone in umbilical cord plasma, late pregnancy, prepubertal children, and adults. J. clin. Endocrin. 29: 891 (1969).

4. Bagshawe, K.B.; Wilde, C.E. and OrR, A.N.: Radioimmunoassay for human chorionic gonadotropin and luteinizing hormone. Lancet $i: 1118$ (1966).

5. Bahn, R.E.; Lorenz, N.; Bennett, W.A. and Albert, A.: Gonadotropins of the pituitary gland during infancy and early childhood. Endocrinology 52: 605 (1953).

6. Berson, S.A. and Yalow, R.S.: Immunoassay of protein hormones; in: G. Pincus, K.V.Thiman and E.B.Astwood: The hormones, Vol. IV (Academic Press, New York 1963).

7. Burr, I.M.; Grant, D.B.; Sizonenko, P. G.; Kaplan, S.L. and Grumbach, M. M.: Some critical factors in double antibody radioimmunoassay systems utilizing anti-rabbit precipitating sera in measurement of serum LH, FSH, and HGH. J. clin. Endocrin. 29: 948 (1969).

8. Burr, I. M.; Sizonenko, P. C.; Kaplan, S. L. and GRUMBACH, M.M.: Observations on the binding of human TSH by antisera to human chorionic gonadotropin. J. clin. Endocrin. 29: 691 (1969).

9. Cheek, D.B.; Migeon, C.J. and Mellits, E.D.: The concept of biologic age; in: D.B. CHEEK: Human growth: Body composition, cell growth, energy, and intelligence, p.541 (Lea \& Febiger, Philadelphia 1968).

10. Donini, P.; Puzzoli, D.; D'Allesto, I.; Lunenthal, B.; Eshkol, A. and Parlow, A.F.: Purification and separation of FSH and $\mathrm{LH}$ from HMG. I. Separation of FSH and $\mathrm{LH}$ by electrophoresis, chromatography and gel filtration procedures. Acta endocrin., Kbh. 52: 169 (1966).

11. Dorfman, R.I. and Shipley, R.A.: Normal pubertal development in boys; in: Androgens: Biochemistry and clinical significance, Chapt. 15 (Wiley, New York 1956).

12. FAIMAN, G. and Ryan, R.J.: Radioimmunoassay for human follicle stimulating hormone. J.clin. Endocrin. 27: 444 (1967).

13. Franchimont, P.: Le dosage des hormones hypophysaires somatotropes et gonadotropes et son application en clinique (Maloine, Paris 1967).

14. Gemzell, C.A.; Diczfalusx, E. and Tillinger, G.: Clinical effects of human pituitary follicle stimulating hormone. J.clin. Endocrin. 18: 1333 (1958).

15. Goodman, H.G.; Grumbach, M.M. and Kaplan, S.L.: Growth and growth hormone. II. A comparison of isolated growth hormone deficiency and 
multiple pituitary hormone deficiencies in $35 \mathrm{pa}$ tients with idiopathic hypopituitary dwarfism. New Engl.J.Med. 278: 57 (1968).

16. Greep, R.O.: Physiology of the anterior hypophysis in relation to reproduction; in: W.G. Young: Sex and internal secretions, Vol.I, p. 240 (Williams and Wilkins, Baltimore 1961).

17. Greulich, W.W. and Pyle, S.I.: Radiographic atlas of skeletal development of the hand and wrist, 2nd ed. (Stanford Univ. Press, Stanford, Calif. 1955).

18. Hoogstra, M.J. and Paesi, F.J.A. : A comparison between the FSH and ICSH contents of the hypophysis of adult and immature rats. Acta physiol. pharmacol. neerl. 4: 395 (1955).

19. Hunter, W.M. and Greenwood, F. C.: Preparation of ${ }^{131}$ I-labeled $\mathrm{HGH}$ of high specific activity. Nature, Lond. 194: 495 (1962).

20. Johanson, A.; Mrgeon, C. J.; Lrght, C.; Guyda, H. and Blizzard, R. M.: Serum luteinizing hormone (LH) in normal boys by radioimmunoassay. J. Pediat. 74: 416 (1969).

21. KaPlan, S. L. and Grumbach, M. M.: Immunoassay for human chorionic 'growth hormone prolactin' in serum and urine. Science 147: 751 (1965).

22. Kragt, C.L. and Ganong, W. F.: Pituitary FSH content in the male rat at various ages. Proc. Soc. exp. Biol., N.Y. 128: 965 (1968).

23. Kulin, H.E.; Rifkind, A.B. and Ross, G.T.: Bioassay determinations of luteinizing hormone (LH) and follicle stimulating hormone (FSH) in adult male plasma. J. clin. Endocrin. 28: 100 (1968).

24. Kulin, H.E.; Rifkind, A.B. and Ross, G.T.: Human luteinizing hormone $(\mathrm{LH})$ activity in processed and unprocessed urine measured by radioimmunoassay and bioassay. J. clin. Endocrin. 28: 543 (1968).

25. Lauson, H.D.; Golden, J.B. and Sevringhaus, E.L.: The gonadotrophic content of the hypophysis throughout the life cycle of the normal female rat. Amer. J. Physiol. 125: 396 (1939).

26. Lytton, N. and KASE, N.: Effects of human menopausal gonadotropin on an eunuchoidal male. New Engl.J. Med. 274: 1061 (1966).

27. McArtuur, J.W. and Antoniades, H.N.: in: A. Albert: Human pituitary gonadotropins, pp. 201-209 (Thomas, Springfield, Ill. 1961).

28. McArthur, J.W.; Pennell, R.B.; Antontades, H.N.; Ingersoll, F.M.; Oncley, J.L. and ULFELDER, H.: Distribution and partial purification of pituitary gonadotropins of human plasma. Proc. Soc. exp. Biol., N.Y. 93: 405 (1956).

29. Midgley, A.R., Jr.: Radioimmunoassay for human chorionic gonadotropin and human luteinizing hormone. Endocrinology 79: 10 (1966).
30. Mrdgley, A.R., Jr.: Radioimmunoassay for human follicle stimulating hormone. J.clin. Endocrin. 27: 295 (1967).

31. Mills, X.H.; Brooks, R.U. and Prunty, F.T.G.: The relationship between the production of cortisol and of androgen by the human adrenal, in: A. R. Gurrie, T.Symington, and J.K. Grant: The human adrenal cortex, p. 204 (Livingstone, Edinburgh 1962).

32. Morgan, G.R. and Lazarow, A.: Immunoassay of insulin using a two antibody system. Proc. Soc. exp. Biol., N.Y. 110: 29 (1962).

33. Odell, W.D.; Ross, G.T. and RAYFord, P.L.: Radioimmunoassay for luteinizing hormone in human plasma or serum: Physiological studies. J. clin. Invest. 46: 248 (1967).

34. Parlow, A.I.: Bioassay of pituitary LH by depletion of ovarian ascorbic acid; in: A. Albert:

* Human pituitary gonadotropins, p. 300 (Thomas, Springfield, Ill. 1961).

35. Raiti, S. ; Johanson, A.; Light, C.; Migeon, C.J. and BlizzARD, R. M.: Measurements of immunologically reactive follicle stimulating hormone in serum of normal male children and adults. Metabolism 18: 234 (1969).

36. Reichert, L.E.: Selective inactivation of the luteinizing hormone contamination in human follicle stimulating hormone preparations by digestion with $\alpha$-chymotrypsin. J.clin. Endocrin. 27: 1065 (1967).

37. Reichert, L.E.; Rathman, R.H. and Ryan, R.J.: Studies on the composition and properties of immunochemical grade human pituitary follicle stimulating hormone (FSH), comparison with luteinizing hormone. Endocrinology 82: 109 (1968).

38. Rrfkind, A.B.; Kurin, H.E. and Ross, G.T.: Follicle stimulating hormone (FSH) and luteinizing hormone (LH) in the urine of prepubertal children. J.clin. Invest. 46: 1925 (1967).

39. Root, A.W.; Moshing, T.; Bongiovanni, A.M. and EBERLEIN, W.R.: The relationship of plasma luteinizing ( $\mathrm{LH})$ concentration to gonadal function (Abstract). 38th Meet. Soc. Pediatric Research, May 1968.

40. Ryan, R.J.: The luteinizing hormone content of human pituitaries. I. Variation with sex and age. J.clin. Endocrin. 22: 300 (1962).

41. RYAN, R.J.: On obtaining luteinizing and follicle stimulating hormones from human pituitaries. J. clin. Endocrin. 28: 886 (1968).

42. Saxena, B.B.; Demura, H.; Gandy, H.M. and Peterson, R.E.: Radioimmunoassay of human follicle stimulating and luteinizing hormone in plasma. J.clin. Endocrin. 28: 519 (1968).

43. Saxena, B.B. and Rathman, P.: Purification of 
follicle stimulating hormone from human pituitary glands. J.biol. Chem. 242: 3769 (1967).

44. Schalch, D. S.; Parlow, A. F.; Boon, R. G. and ReIchlin, S.: Measurement of human luteinizing hormone in plasma by radioimmunoassay. J. clin. Invest. 47: 665 (1968).

45. Simpson, M.E.: Comparison of follicle stimulating and interstitial cell stimulating properties of gonadotropins from pituitary and non-pituitary sources; in: A.Albert: Human pituitary gonadotropins, p. 352 (Thomas, Springfield, Ill. 1965).

46. Sizonenko, P. G.; BurR, I. M.; KAPLAN, S. L. and Grumbach, M. M. : Hormonal changes in puberty. II. Correlation of serum luteinizing hormone and follicle stimulating hormone with stages of puberty and bone age in normal girls. Pediat. Res. 4: 42 (1970).

47. Sniffen, R.C.: The testis. I. The normal testis. Arch.Path.Lab. Med. 50: 259 (1950).

48. TAnner, J.M.: Growth at adolescence, 2nd ed. (Blackwell Scientific Publications, Oxford 1962).

49. Wells, L.J.: Descent of testis: Anatomic and hormonal considerations. Surgery 14: 436 (1943).

50. Wide, L. and Gemzell, C. : Immunological detection of pituitary luteinizing hormone in urine of fertile and postmenopausal women and adult men. Acta endocrinol. 39: 539 (1962).

51. WrTschI, E.: Bioassay for FSH content of human hypophyses in human pituitary gonadotropins; in: A. Albert : Human pituitary gonadotropins, p. 349 (Thomas, Springfield, Ill. 1961).

52. Follutein, E. R. Squibb \& Sons, New York.
53. Provided by Dr. Harold PAPKoff (potency equivalent to 1 NIH-FSH-S $1 \mathrm{U} / \mathrm{mg}$ ).

54. Provided by Dr. W. Odell, distributed by the National Pituitary Agency (NPA).

55. Provided by Dr. Leo E. Reichert, distributed by NPA.

56. Second International Reference Preparation (2nd IRP), obtained from the National Institute of Medical Research, Mill Hill, London, England.

57. Obtained from Cambridge Nuclear, IsoServ Division, Cambridge, MA.

58. Distributed by NPA.

59. We thank Dr. Henry Shinefield, Director of the Pediatric Kaiser Hospital Multiphasic Screening Program for his generous cooperation and enthusiastic support.

60. Dr. Tan M. Burr and Dr. Pierre C. Sizonenko are recipients of a National Institutes of Health International Research Fellowship. Dr. SELnA L. KaPlan is a recipient of Research Career Development Award, National Institutes of Health.

61. This work was prepared with the assistance of Dr. Constance Allen.

62. Supported in part by Public Health Service Research grants from the National Institute of Child Health and Human Development and the National Institute of Arthritis and Metabolic Diseases, NIH.

63. Requests for reprints should be addressed to: MELvin M.Grumbach, M.D., Department of Pediatrics, University of California, San Francisco Medical Center, San Francisco, CA 94122, USA.

64. Accepted for publication September 2, 1969. 